Article

\title{
Resilient or Not: A Comparative Case Study of Ten Local Water Markets in China
}

\author{
Yi Liu *D, Peng Li and Zhiwei Zhang \\ Department of Public Administration, Dalian University of Technology, Dalian 116023, China; \\ Lipeng@dlut.edu.cn (P.L.); zzw2017@mail.dlut.edu.cn (Z.Z.) \\ * Correspondence: liuyi_bnu@dlut.edu.cn; Tel.: +86-411-84707476
}

Received: 2 October 2018; Accepted: 30 October 2018; Published: 2 November 2018

\begin{abstract}
Despite the global expansion of water markets, their resilience has received little scholarly attention, even though they are vulnerable to external and internal disturbances. Since the 1990s, the water market has been actively promoted by China as an important institutional coordination mechanism for efficient water use. This article examines what contextual factors, in configurations, contribute to the resilience of water markets in China. We distinguish between resilient and factitious water markets as two outcome variables and distil four conditions from market environmentalism to explain the variance in their outcomes: ownership of water entitlements, market intermediaries, water pricing, and spot/forward trade categories. Using crisp-set qualitative comparative analysis (csQCA), we analyzed seven resilient and three factitious water markets in China. Our findings show that a water market's framework is multidimensional and complex and that no necessary conditions contribute to resilience. Two sufficient solutions display the configurational complexity of water markets' resilience. Path 1 includes strong intermediary, uncompetitive price, and forward water trade. Path 2 includes privatization of water entitlements, spot contracts, and competitive pricing. Weak intermediary together with forward water trade determines factitious water markets. The QCA results reveal that there exist multiple paths that a resilient water market can follow and develop. Therefore, policymakers must be cautious about pushing for water market indiscriminately, especially by over-privatization and unlimited investment in water banks.
\end{abstract}

Keywords: water rights trading; market environmentalism; resilience; qualitative comparative analysis

\section{Introduction}

Water markets, or water rights trading (WRT), have been operational in China since the 1990s [1-3]. A proliferating demand for water resources resulting from rapid urbanization and industrialization is challenging the country's sustainable development because of conflicts over water use $[4,5]$. Suffering from water scarcity, together with an uneven distribution of water resources in spatial and temporal terms, China has started to establish formal water markets to improve the efficiency of water allocation and to alleviate the shortage of natural water resources. In comparison with the traditional authoritarian way of water allocation and resources management, China now seems to be moving towards a market-oriented system. The number of water markets is still limited [6]. Nevertheless, pilot water markets driven both by potential trading parties and by water agencies are taking shape in China.

In 2005, the Ministry of Water Resources (MWR) in China promulgated a regulation stipulating the transfer of water rights for the sustainable utilization of water resources [7]. The fundamental rules consist of governmental regulation with market mechanisms, well-defined property rights, paid transfer, and reasonable compensation. To date, China has over 20 local water markets recognized by the MWR, spread over 16 provinces. However, not all these water markets are resilient, and the 
underlying causes for this are not critically examined in the literature. The well-performing ones enjoy nationwide prestige and are widely advocated for their lessons, implying official endorsement of WRT expansion. In contrast, some water markets (designated in this study as factitious) equipped with all the necessary ingredients, such as full-cost water price, trading platform, storage, and a transfer system, stagnated after one or two WRT operations and left piecemeal information to the public. In some extreme cases, water markets even broke down, in particular when water resource management was contracted out to private businesses, which, in drought seasons, were inclined to hoard water $[8,9]$. Therefore, against this backdrop, water market resilience is extremely meaningful in China. Given that the authoritarian regime has the power to mobilize actors, i.e., whenever a national strategy is formed, local governments are subsequently required to respond with policy implementation [10], vertical mandatory intervention of WRT by central government could generally diffuse the useful lessons learned from ex-ante water markets but, conversely, could also push for water markets without a contextual policy design [11]. This situation happens most often when a water market is involved in peer-government competition, for example in response to central government's policy advocacy [12].

The literature stresses that the conditions contributing to a resilient water market are contextualized and work in combination, making them difficult to replicate [11]. Even though there is no common agreement on what constitutes a "right design", several conditions have been elucidated for water markets' efficient outcome. Most of the frameworks include hydrology [13], tradable water rights [14], free information flow [15], market pricing [15,16], monitoring [17,18], and local governance [19]. However, they reveal little about which conditions are necessary and which conditions are sufficient, or about how they work together. For a better understanding of water market resilience, we need "some degree of approximation to establish the conditions for the occurrence of the phenomenon" [20] (p. 267). Hence, this study examined one critical question: What contextual factors, in configurations, contribute to the resilience of water markets in China? To do this, we developed an empirical framework inspired by market environmentalism and, using crisp-set qualitative comparative analysis (csQCA), examined ten cases of local water markets in China. The findings are discussed here, and the paper ends with conclusions.

\section{Conceptual Framework}

In this section, we aim to clarify two main issues: the definition of water market resilience and the variable conditions explaining outcome variances.

\subsection{Defining Water Market Resilience in Social-Ecological Systems}

A water market is a coupled social-ecological system consisting of human-nature interactions. Water market resilience, in this article, encompasses a twofold meaning in response to the famous question in the resilience literature, "resilience to what" and "resilience of what" [21]. In response to the first aspect, water market resilience could be perceived as its sustainability, the "capacity of a system to undergo disturbance and maintain its functions and controls" [22]. Despite water markets' prima facie advantages, their resilience has been frequently questioned in the literature, which argues that water markets are vulnerable to external and internal disturbances, notably, drought [23], conflicts [24], bad water governance [21], and strong deregulation [25]. However, little has been suggested about how to improve a water market's resilience. This issue relates to the second aspect of the question: What configurations should a water market retain and when does it need to switch from one to others to maintain the system's equilibrium [26]? In the water sector, it is commonly acknowledged that water market operations are contingent on a number of factors, including policy enactment [13], investment in water usufruct [27,28], tradable water rights [14], and free information flow [15]. However, their constituent configurations have yet to be identified. For instance, as a market intermediary is a crucial building block initiating water trading [29], would it be better to switch from bulletin boards to water banks to safeguard water market functions in a water stress period? From a configurational perspective, the water market framework is multidimensional and complex, and the effect of a strong intermediary 
depends on the presence or absence of one or several other factors [30]. Hence, the answer to the question is ambiguous.

In this article, we are not trying to comprehensively measure water market resilience; instead, we intend to operationalize this concept into an observable indicator, out of its many disparate definitions. The engineering approach defines resilience as elasticity without breaking [31]. Institutional theory suggests that the resilience of a system lies in specific investments, that is, the continued flow of resources, to ensure its legitimacy [32]. Therefore, it is reasonable to conclude that on-going water transactions should be the fundamental property of a resilient water market [33]. Furthermore, when the cost associated with the development of water market is considered, often recorded before its adoption [34], the primary investments needed to initiate the function are a sunk cost [35], which is not recoverable whenever a water market fails to attract potential traders, not to mention the political goals for efficient water use. On the assumption that "resilience in one time period was gained at the expense of the succeeding period" [36], the indicator adopted also encompasses the temporal scale of water market resilience.

Therefore, we emphasize the ongoing transactions in water markets as representative of their resilience, instead of critically examining the more usually considered outcome of water use efficiency and conservation. Even though identifying the various configurations of a resilient water market is a challenging task [37], we aim to distil contextual conditions from the literature, in a configurational approach, to explain the variance in resilience.

\subsection{The Variable Conditions Explaining the Outcome Variances}

As found in the literature, clearly defined property rights, free marketing, water valuation, and pricing constitute the core of WRT [38-40]. From this generic model, we develop an empirical framework from the open system perspective, containing the contextual factors within formal water market mechanisms [41], as well as the external environment influencing institutional change [42].

\subsubsection{The Ownership of Water Entitlements}

Different from formal property rights, a water right is a legal entitlement; this means that the owner actually holds the license for water use rather than owning the water itself. Furthermore, this ownership entails many restrictions imposed by the government [43], given that water resources are vested in the sovereign power in many countries [44]. Such institutional features illuminate the status of the "clearly defined property right" to trade water trading, partly explaining why much of the literature supporting free market environmentalism implicitly assumes that the more privatized the water entitlement is, the more efficient water markets are $[40,45,46]$. In this vein, property theorists prefer individuals rather than the community or the state to hold the water rights, given the alternative possibility of water being held free of charge and therefore having less value [47]. Compared with state-owned or communal water rights, private water rights can exclude others from using water, thus internalizing the cost and benefits of its use and conservation [47]. Therefore, the ownership of water entitlements is a contextual factor of a water market $[28,33]$.

\subsubsection{Market Intermediaries}

Transaction costs and transfer costs are the most usual factors blocking water markets [34], creating the necessity for market intermediaries prior to the development of water markets. Taking the case from the Murray system in Australia, Bjornlund and McKay [48] found that market intermediaries determine water markets' maturation and that inadequate information flows lead to a lower water price and attract opportunistic, inefficient buyers. A water market's capacity also relies heavily on its physical attributes, i.e., the extent to which the hydraulic infrastructure can integrate a water body [49], implying the significance of strong intermediaries capable of investment, contract provision, and insurance to cover trading. There are various types of market intermediaries throughout the world [29]. However, among those, water banks' influence is much stronger than that of the other types owing to their capacity to stock and transfer water. Judging by their significance in water markets, it seems 
reasonable that the literature sometimes simply equates water market mechanisms to intermediaries, i.e., transferring water between traders.

\subsubsection{Water Pricing}

One argument that market environmentalism makes against the state's hydraulic paradigm is water's underpricing in key sectors, which threatens the sustainability, efficiency, and equality of water use [38]. A set of pricing techniques has been explored for the full-cost pricing of water resources, including ecological externalities and supply cost in the price calculation. The competitive market and pricing are fundamental tenets of neo-classical economic theory upon which market environmentalism builds, and some scholars have proposed the comparable advantage of market pricing in enhancing water use efficiency [50,51], challenging the stability of a fixed water price for breaking even financially [52]. However, water pricing is undoubtedly a key element contributing to global water market reform.

\subsubsection{Trade Categories}

To counteract external uncertainties, variable trading arrangements have been designed to sustain a successful water market. Calatrava and Garrido [53] found that centralized water markets are more efficient than decentralized markets when farmers are facing water supply uncertainties. In Australia, where water markets are most mature, eight trading mechanisms have been developed to expand trading scale [54]. A careful and robust market design is not easy to achieve due to the complexity of assessing the uncertainties and predicting traders' responses, commonly resulting in policy bias, such as focusing on broadening permanent water markets to reduce transaction costs [55]. More attention needs to be paid to the role played by authority in water market design, especially in state-sponsored water markets, where irrigators may resist water trading because of their potential loss of benefit [56]. Water market efficiency actually depends on risk sharing among participants [57], which in turn calls for a liberalization of governance according to market environmentalism scholars [38].

\section{Case, Methods and Materials}

Notwithstanding market environmentalism's global expansion in the water sector, evidence-based results of such practices are quite sparse, limited to several cases from Australia and America. These cases from China are sufficient to permit comparison, whereby "a maximum of heterogeneity over a minimum number of cases should be achieved" [58].

\subsection{Understanding the Heterogeneity of Local Water Markets in China}

To structure the heterogeneity of local water markets in China, we adopt the framework described in Section 2 to operationalize the most-similar/different-outcome (MSDO) design in comparative case studies.

\subsubsection{Who Owns the Right to Trade Water}

In China, there are two types of ownership institutionally at state level [59], state owned and communal owned. The latter refers to the water in the ponds belonging to rural communities and in the reservoirs constructed and managed by them. The watershed authorities and the water agencies in local governments manage water rights through licensing to privatize the annual water quota, i.e., water entitlements to water users, constituting the hierarchical framework of the water entitlement system. However, because of the state hydraulic paradigm, the substantive ownership of water resources in China is distinctly diverse, with the majority of local water agencies in charge of water resources, in the name of unified administration and supervision.

In general, the nation currently allows the privatization of water entitlements to rural communities or water user associations (WUAs) in an effort to clarify water entitlements [60]. Some local water markets, such as Zhangye water market, even assign water entitlements to rural households for irrigation. 


\subsubsection{Intermediary Types}

To promote water markets, local water agencies established water banks or bulletin boards to bring the water traders together, or at least brokered the potential trading parties. Some water banks are commercialized, as in Ordos and Baotou. State-owned corporations were technically set up to finance the physical investment, to establish stocking water entitlements, and to deal with industrial purchasers. Public-private partnership (PPP) projects have flourished in China since 2014, and some PPP companies operate as local water banks. The other type of intermediary in China is the bulletin board, or trading platform, mainly for trading information transfer. Some local water markets rely on a closed platform within WUAs (Zhangye, Inner Mongolia), and some establish public online WRT platforms sharing trading information. In 2016, co-sponsored by the MWR, the first nationwide WRT platform was set up, visualizing the state's ambition for a universal national-scale water market.

\subsubsection{How Water Price Is Determined}

Water Law 2009 in China consolidated market environmentalism in the water sector by market-based water pricing; however, it leaves room for administrative water pricing that includes the full cost water price. As the law stressed more the supply side of water pricing, without specifically recognizing water scarcity, some local governments (in Ordos, Baotou, and Manasi) were inclined to set the fixed price directly to cover the supply-related costs, either from service operator companies or from public finance.

Very few local governments acknowledge free market pricing, where the trading price is determined through bargaining, an outcome reflecting demand and supply (Dongtiao River). In many other cases, local governments govern the water markets by setting a benchmark price, either a capped price or a bottom price. In Dongping, the regulation imposes the full cost water price mostly on the water bank in the case of water stocking and leaves purchasers free to engage in auctions.

\subsubsection{The Uncertainties Entailed in Trading Contracts}

The local water markets in China practice two categories of trade contract-spot water trade and forward water trade- thereby significantly structuring the uncertainties faced by local water markets, especially in a thin market where the market is dependent on several purchasers. The water market in Zhongning is factitious now, with a long-term 15-year contract, because the purchaser is in bad shape economically. To eliminate the uncertainties, local governments in Ordos, Baotou, and Manasi followed a top-down approach in market design to guarantee the long-term forward water trade. In 2016, the MWR stipulated that no administrative approval was needed if the WRT contract between irrigators lasted for less than one year. Otherwise, it has to be reported to the local water agency, which in turn institutionally stresses the uncertainties in forward water trade and the relevant bureaucracies' responsibilities [61].

Even though there are over 20 local water markets throughout China, we chose the most representative ones on the basis of three criteria: (1) officially recognized, by either the MWR or reported in national newspapers, at least advertised on official websites at province level; (2) geographically inclusive: besides the cases from the arid areas in north China, we include cases from pluvial areas in the south; and (3) testable performance: the spectrum of our cases runs from the early 2000s to 2017, each with a history of at least three years. Noticeably, after 2014, several water markets were established at province level, but their resilience is hard to define given their limited duration. In sum, our data collection followed the principle of holistic similarity and configuration difference required by csQCA [58]. Data were collected through databases, documents available from websites, and semi-structured interviews with the responsible officers working in the local water agencies $(n=15)$ and four water experts who acted as consultants for the MWR between September 2016 and August $2018(n=4)$. The spatial structure of the ten cases is shown in Figure 1, and their contextual conditions are shown in Table 1. 
Table 1. Contextual situations of the 10 local water markets in China.

\begin{tabular}{|c|c|c|c|c|c|c|c|c|}
\hline Water Market & Abbr. & Province & From & Outcome & Owner & Intermediaries & Water Price & Trade Category \\
\hline Ordos & ED & Inner Mongolia & 2003 & Resilient & Local water agencies & $\begin{array}{c}\text { Water Rights Conversion } \\
\text { Construction Management Office }\end{array}$ & Fixed price & $\begin{array}{l}\text { Forward trade } \\
\quad(25 \text { years })\end{array}$ \\
\hline Baotou & BT & Inner Mongolia & 2005 & Resilient & Local water agencies & $\begin{array}{l}\text { Water Rights Conversion } \\
\text { Construction Management Office }\end{array}$ & Fixed price & $\begin{array}{l}\text { Forward trade } \\
\quad(25 \text { years })\end{array}$ \\
\hline Manasi & XJ & Xinjiang & 2014 & Resilient & Households & BiYuan water supply company & Fixed price & Forward trade \\
\hline Yuanmou & YM & Yunnan & 2014 & Resilient & Households & PPP company & Capped price & Spot trade \\
\hline Shiyang River & SY & Gansu & 2008 & Resilient & Households & Shiyang River WRT platform & Capped price & Spot trade \\
\hline Shule River & SL & Gansu & 2014 & Resilient & WUAs & Shule River WRT platform & Capped price & Spot trade \\
\hline Zhangye & $\mathrm{ZY}$ & Gansu & 2002 & Resilient & Households & Zhangye WRT center & Capped price & Spot trade \\
\hline Dongping & SD & Shandong & 2014 & Factitious & $\begin{array}{l}\text { Industrial water } \\
\text { users/Households }\end{array}$ & $\begin{array}{l}\text { Dongping public resources } \\
\text { trading platform }\end{array}$ & Capped price & Forward trade \\
\hline Dongtiao River & DT & Zhejiang & 2014 & Factitious & $\begin{array}{l}\text { Industrial water } \\
\text { users/Rural communities }\end{array}$ & $\begin{array}{l}\text { Hangzhou public resources } \\
\text { trading platform }\end{array}$ & Free market price & $\begin{array}{l}\text { Forward trade } \\
\quad(3 \text { years })\end{array}$ \\
\hline Zhongning & $\mathrm{ZN}$ & Ningxia & 2015 & Factitious & Local water agencies & Zhongning WRT platform & Fixed price & $\begin{array}{l}\text { Forward trade } \\
\quad \text { (15 years) }\end{array}$ \\
\hline
\end{tabular}




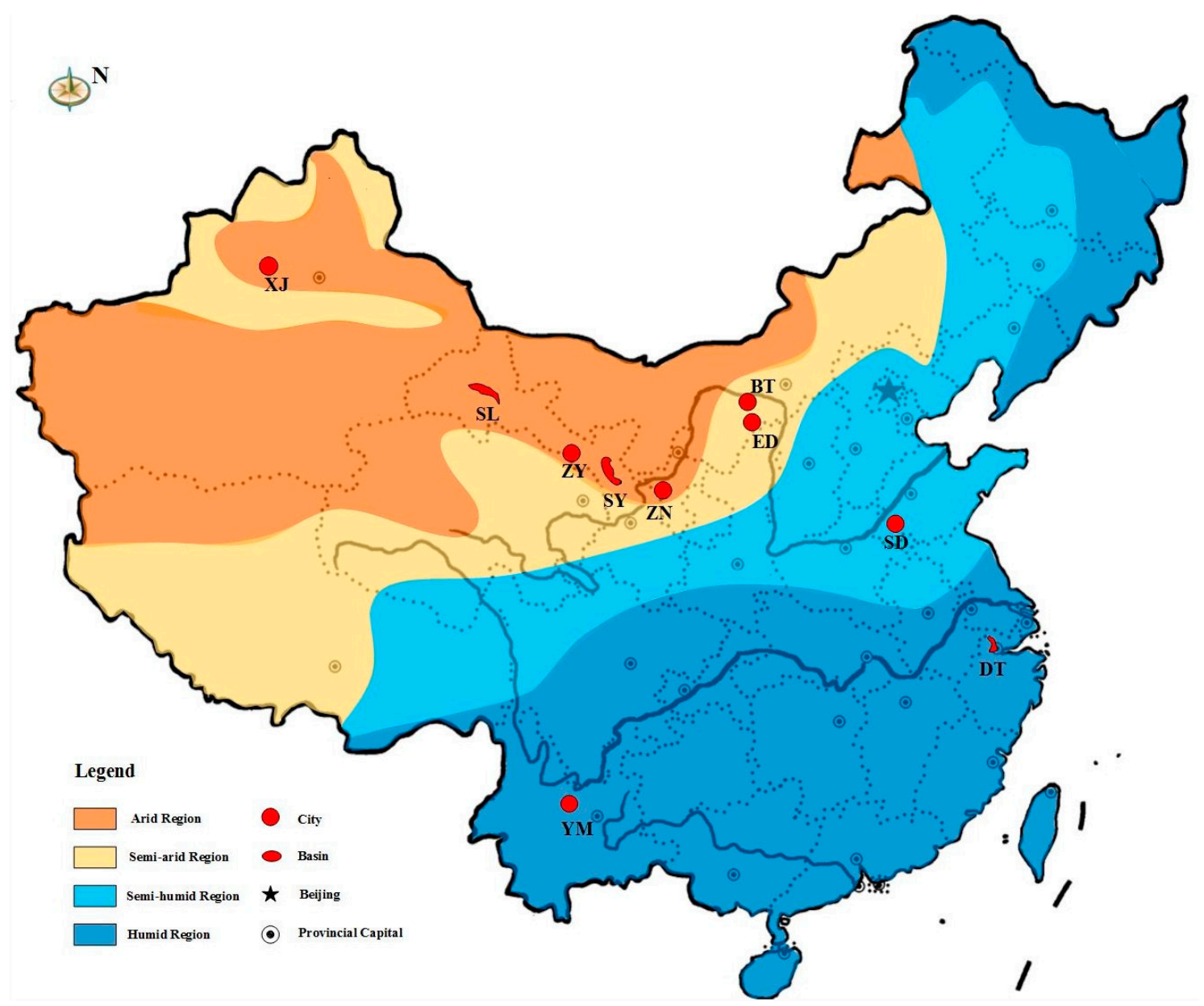

Figure 1. Spatial structure of ten local water markets in China.

\subsection{Qualitative Comparative Analysis (QCA) and Data Calibration}

The aim of this article is to ascertain the necessary or sufficient conditions contributing to a resilient water market, and how they work together. To do so, QCA, i.e., Qualitative Comparative Analysis, a case-sensitive method developed by Charles Ragin, was used [58]. It has unique advantages for small-N research designs, providing a holistic perspective on the cases and examining the conditions as a complex combination [62]. It "starts by assuming causal complexity and then mounts an assault on that complexity" [63] (p. X). This so-called configurational thinking is inherently compatible with resilience studies. In this article, the resilience of local water market is considered as the outcome and the four conditions are examined as potential causal conditions. There are three main versions of QCA: csQCA (crisp-set QCA), fsQCA (fussy-set QCA), and mvQCA (multi-value QCA). In comparison with the other two methods, csQCA is rather simple; however, it is more applicable to small-N cases, in which the outcomes and the conditions can be denominated as bivalent crisp-set data, using the Boolean logic values 0 or 1 [58]. The outcome variance in this article is "resilient or not", of a dichotomous nature, describing the "present" or the "absent" state. The conditions explaining the outcome are also classified variables, which could be dichotomized to fit into the research design. Therefore, we chose csQCA for the data analysis.

Firstly, we need to calibrate the qualitative data into a dichotomous data table. The four contextual conditions, as well as the outcome, are calibrated into value 1 or 0 , with an overview in the following context, entailing more elaboration on the details in accordance with the calibration procedure [58]. The calibration of resilience is substantive, that is, to see whether the local water market is continuing to operate. The resilient water markets are scored 1 in Table 2 . These markets were identified by more 
detailed case description, such as active water trades with good prospects (from the interviews with the water officers in Baotou, Ordos, Shule River, Manasi, Zhangye, Shiyang River, and Yuanmou). In parallel, the factitious ones are scored 0 , which have few water trades bearing the sunk cost for water delivery services, manifested by contract violations, weak prospects, and interrupted investments (from the interviews with the water officers in Dongtiao River, Dongping, and Zhongning).

- Condition 1: The ownership of water entitlements

This condition is measured by who is actually in charge of the ownership of water entitlements. The National Development and Reform Commission (NDRC) of China's 2017 temporal regulation encourages the privatization of water entitlements to WUAs or rural communities [60]; the conditions in this case score 1 . Note that the local governments have the autonomy to implement the water property reform; this condition scores 0 as it does not accomplish the privatization process. In other cases, water entitlements are allocated to households in irrigation areas; these cases are combined with the first type and also score 1.

- Condition 2: The type of intermediaries

There are two types of institutionalized market intermediaries in China's local formal water markets: the water bank and the bulletin board with various names such as trading platform, water resource management center, or even corporation. The cross-over point is their water stocking capacity in water trades. Once equipped with reservoirs and other storage facilities, water banks are strong intermediaries capable of stocking the dispersed water resources and contracting with purchasers to pursue profits from the water trade (calibrated as 1). By contrast, those intermediaries that are weak—only responsible for information broadcast or trade records—cannot participate in the trade as contracting parties (calibrated as 0 ).

Table 2. Overview of data calibration.

\begin{tabular}{|c|c|c|c|c|}
\hline & Set & Indicator & Case & Score \\
\hline \multirow[t]{2}{*}{ Outcome } & $\begin{array}{c}\text { Resilient } \\
\text { water market }\end{array}$ & Active water trades; good prospects & $\begin{array}{l}\text { BT, ED, SL, XJ, } \\
\text { ZY, SY, YM }\end{array}$ & 1 \\
\hline & $\begin{array}{c}\text { Factitious } \\
\text { water market }\end{array}$ & $\begin{array}{l}\text { Few water trades; contract violations; } \\
\text { weak prospects }\end{array}$ & DT, SD, ZN & 0 \\
\hline \multirow[t]{2}{*}{ Privatization } & $\begin{array}{c}\text { The occurrence of } \\
\text { privatization }\end{array}$ & $\begin{array}{l}\text { Water entitlements allocated to } \\
\text { households, WUAs, or } \\
\text { rural communities }\end{array}$ & $\begin{array}{l}\text { SL, XJ, ZY, SY, } \\
\text { DT, SD, YM }\end{array}$ & 1 \\
\hline & $\begin{array}{l}\text { The absence of } \\
\text { privatization }\end{array}$ & Local water agencies in charge & $\mathrm{BT}, \mathrm{ED}, \mathrm{ZN}$ & 0 \\
\hline \multirow{2}{*}{ Intermediary } & Strong capacity & $\begin{array}{l}\text { Water banks capable of water } \\
\text { stocking; contracting with purchasers; } \\
\text { delivery service investors }\end{array}$ & BT, ED, XJ, YM & 1 \\
\hline & Weak capacity & $\begin{array}{l}\text { Bulletin board for information } \\
\text { broadcast; recording the contract; } \\
\text { brokering trades }\end{array}$ & $\begin{array}{l}\text { SY, ZY, SL, DT, } \\
\text { SD, ZN }\end{array}$ & 0 \\
\hline \multirow{2}{*}{$\begin{array}{l}\text { Competitive } \\
\text { pricing }\end{array}$} & $\begin{array}{l}\text { The presence of } \\
\text { bargaining }\end{array}$ & Flexible, bargaining allowed & $\begin{array}{l}\text { ZY, SY, DT, SD, } \\
\quad \text { SL, YM }\end{array}$ & 1 \\
\hline & $\begin{array}{l}\text { The absence of } \\
\text { bargaining }\end{array}$ & $\begin{array}{l}\text { Fixed, determined by the } \\
\text { water agency }\end{array}$ & $\mathrm{BT}, \mathrm{ED}, \mathrm{XJ}, \mathrm{ZN}$ & 0 \\
\hline \multirow{2}{*}{ Trade categories } & Spot trade & $\begin{array}{l}\text { Dominated by short-term contract for } \\
\text { immediate delivery }\end{array}$ & SY, ZY, SL, YM & 1 \\
\hline & Forward trade & $\begin{array}{l}\text { Dominated by long-term contract for } \\
\text { future delivery }\end{array}$ & $\begin{array}{l}\text { ED, BT, XJ, SD, } \\
\text { DT, ZN }\end{array}$ & 0 \\
\hline
\end{tabular}

- Condition 3: Competitive water pricing

Free market pricing is not observed in China's local water markets. Most of the local water agencies regulate the water price by setting either a bottom price or a capped price. However, water 
pricing can be identified as competitive provided bargaining is allowed and demand-supply can be taken into consideration. Therefore, flexible water prices, or prices that are capable of adjustment without the water agencies' consent, are calibrated as 1 . In our cases, the empirical data contain quite a few fixed water prices calibrated as 0 . This does not mean that they do not change, but rather that they are decided by the water agencies and price bargaining is excluded from water trade negotiations.

- Condition 4: Trade categories

The spot trade is practiced by short-term contracts for intermediate delivery, and the forward trade is practiced by long-term contracts for future delivery. When the interviewees from water agencies were asked to evaluate the social risk from specific water markets, the responses on spot-trade-dominated ones are more positive than the others. Therefore, we calibrate the spot-trade-dominated contracts as 1 and the forward-trade-dominated contracts as 0 .

After the data calibration, we need to run a "synthesis" of the raw data table, using the fs /QCA software [64], to get a table of configurations, i.e., the combination of conditions contributing to a given outcome. This is called a truth table.

The truth table derived from our data is shown in Table 3. It indicates two separate outcomes and six configurations corresponding to ten observed cases. Four configurations can explain resilient water markets, and two configurations can explain factitious markets.

Table 3. Truth table.

\begin{tabular}{ccccccc}
\hline \multirow{2}{*}{ Row } & Case & \multicolumn{4}{c}{ Condition $^{\mathbf{1}}$} & Outcome \\
\cline { 3 - 7 } & & E & I & P & D & R \\
\hline 1 & ED, BT & 0 & 1 & 0 & 0 & 1 \\
2 & XJ & 1 & 1 & 0 & 0 & 1 \\
3 & YM & 1 & 1 & 1 & 1 & 1 \\
4 & SY, SL, ZY & 1 & 0 & 1 & 1 & 1 \\
5 & SD, DT & 1 & 0 & 1 & 0 & 0 \\
6 & ZN & 0 & 0 & 0 & 0 & 0 \\
\hline
\end{tabular}

${ }^{1}$ E, Privatization; I, Intermediary; P, Competitive Pricing; D, Trade Categories; R, Resilience.

\section{Empirical Findings}

\subsection{Explaining Why Some Local Water Markets Are Resilient}

We firstly tested the necessary conditions causing water markets' resilience; more specifically, an outcome will not occur if a cause is not present. By doing this necessity analysis, we aimed to check whether there is a condition present in all configurations, logically resulting in equifinality with a consistency threshold of 1 or at least over 0.9 by calculation [58]. The consistency score 0.9 means that, when an outcome occurs, a condition "almost" always exists; a score of 1 means that a condition always exists. This consistency threshold guarantees the strength of the necessity relationship; however, it should be considered alongside the coverage score. A coverage score below 1 means that, on some occasions, when the condition exists, the outcome does not follow. The full score of 1 for both coverage and consistency of a condition always confirms necessity with regard to an outcome. This necessity test-the results of which are shown in Table 4, where all conditions' consistency ranges from 0.285 to 0.714-implies the absence of necessary conditions for a resilient water market and narrows down the explanation for the outcome occurrence to a configurational sufficiency solution.

By using the fs/QCA software, we can minimize the configurations with a 1 outcome and a 0 outcome separately and, in this way, connect the cases with the same outcome to the minimal formula, called solution or path in QCA analysis. The aim of this step using Boolean minimization algorithms is to detect the casual relation between the contextual conditions, in combination, and the diverging outcomes. Through pairwise comparison, selectively reducing logical remainders and analyzing the truth table using Boolean equations, three types of solutions can be obtained: a complex solution, 
a parsimonious solution, and an intermediate solution. We opted for the complex solution for further discussion, in that the parsimonious solution is far too simple, including all the logical remainders and contradicting the empirical evidence in our cases. We did not choose the intermediate solution, where logical remainders with theoretical basis are included, fuzzing the boundary between the theoretical hypotheses and factual analysis [58,62].

Table 4. Necessary conditions for a resilient water market.

\begin{tabular}{ccc}
\hline Conditions & Consistency & Coverage \\
\hline $\mathrm{E}$ & 0.714 & 0.714 \\
$\sim \mathrm{E}$ & 0.285 & 0.666 \\
$\mathrm{I}$ & 0.571 & 1.000 \\
$\sim \mathrm{I}$ & 0.428 & 0.500 \\
$\mathrm{P}$ & 0.571 & 0.666 \\
$\sim \mathrm{P}$ & 0.428 & 0.750 \\
$\mathrm{D}$ & 0.571 & 1.000 \\
$\sim \mathrm{D}$ & 0.428 & 0.500 \\
\hline
\end{tabular}

Two complex solutions explain the resilience of water markets. The formula is $I^{*} \sim P^{*} \sim D+E^{*} D^{*} P=1$. Note that we find no necessary conditions in the above necessity test; however, we can identify several sufficient conditions for a resilient water market. A condition is sufficient but not necessary if it contributes to the outcome, working together with other conditions. Regarding our empirical framework, all four contextual conditions are sufficient to the outcome; however, combining differently in two solutions. In Path 1, intermediary with strong capacity (water bank), uncompetitive price, and forward water trade contributes to a resilient water market. In parallel, Path 2 contributing to a resilient water market combines privatization of water entitlements, spot contract, and competitive pricing.

The score on solution consistency and solution coverage is strong to 1 . The former means that there is a strong casual relation between the path and the outcome [65]; whenever either path manifests itself, a resilient water market is sure to be present. The latter means that all the cases resulting $1 \mathrm{can}$ be completely explained by the two solutions provided. We have the same score with unique coverage and raw coverage, which means that the conditions are not correlated and the solutions do not overlap one another. Here, the $I^{*} \sim P^{*} \sim D$ path uniquely explains $42.8 \%$ of cases that some local water markets can operate resiliently, and the $E^{*} D^{*} P$ path uniquely explains $57.1 \%$ of the other cases. Details of each path are shown in Table 5.

Table 5. Complex solution for resilient water market.

\begin{tabular}{ccc}
\hline Path & $\mathbf{I}^{*} \sim \mathbf{P}^{*} \sim \mathbf{D}$ & $\mathbf{E}^{*} \mathbf{D}^{*} \mathbf{P}$ \\
\hline Case & $\mathrm{ED}, \mathrm{BT}, \mathrm{XJ}$ & $\mathrm{SY}, \mathrm{ZY}, \mathrm{SL}, \mathrm{YM}$ \\
Raw Coverage & 0.428 & 0.571 \\
Unique Coverage & 0.428 & 0.571 \\
Solution Coverage & 1 & 1 \\
Solution Consistency & 1 & 1 \\
\hline
\end{tabular}

Path 1 covers three local water markets: Manasi (XJ), Ordos (ED), and Baotou (BT). They all set up state-owned companies engaging in the forward water trade, by service-delivery investment, paying compensation to irrigators, and ensuring the trade performance within the contract spectrum. The industries with which those intermediaries are contracting are essential to the local economy, but they challenge water trading because of the complicated water service delivery systems distributed over a vast area, making it unprofitable for private companies to become involved. Eventually, local governments became the prime investors in water bank companies. In a telephone semi-structured interview in October 2017, Mr. Zhang-an engineer of the Ordos City Water Affairs Bureau—said that in Ordos (2009-2011) the municipality gave a 500 million yuan subsidy to the water company to 
integrate the water transfer service system [66]. In Manasi, Mr. Zhu-head of the Taxi River Basin Management Office-told us during a telephone semi-structured interview in December 2017 that the transfer project cost 120 million yuan, and the municipality took a $51 \%$ share to preside over water companies' operations. Water agencies' dominant position in water bank companies makes the uncompetitive water price pertinent, in terms of the supply-related costs. Manasi set the water price at 1.5 yuan per cubic meter to industrial purchasers, with an acquisition cost at 0.462 yuan, and the nominal profit is barely capable of covering the cost of water purification [67]. Furthermore, the water agencies in Manasi explained to the irrigators that, once the operating cost declines, alongside the future development of the water market, the surplus will be distributed to them by raising the purchase price (interview: Mr. Zhu, head of the Taxi River Basin Management Office). Ownership of water entitlements is not sufficient for water markets' resilience in these cases, in that Ordos and Baotou have not finished the privatization process of water entitlements whereas Manasi has already done so.

Four water markets fit into the second path: Shule River (SL), Shiyang River (SY), Zhangye (ZY), and Yuanmou (YM). The former three water markets are all located in an arid province, Gansu, upstream of Yellow River in north China. As an undeveloped province, Gansu is very dependent on agriculture. However, it has been institutionally constrained by water scarcity since 1987, when the central government envisioned the Plan of the Available Supply for Water Distribution for the Yellow River [68] to resolve the ecological catastrophes caused by the Yellow River drying out. Yuanmou water market in Yunnan province displays features similar to the other three cases. As a vegetable production base, this county increasingly suffers from water scarcity resulting from industrial development and climate change. Theoretically, the privatization of water entitlements could create incentives for water saving among irrigators. As the pioneering pilot water market in China, Zhangye distributed water entitlements to rural households in the form of a "water ticket". With national funding support, Zhangye water market was able to afford the "expensive yet miraculous" water delivery-service system for clearly defining property rights (interview: Head of Zhangye City Water Affairs Bureau, anonymous). The water market in the Shiyang River basin duplicated the Zhangye model. The water market in Shule River consented to the allocation of water entitlements to WUAs or rural communes (interview: Head of Water Resources Department of Gansu Province, anonymous). Most of the water trades in the above markets are spot trades, specifically for the irrigation seasons; this significantly reduces both the uncertainties and the negative externalities in contrast to the forward water trade over a time spectrum. Despite setting a benchmark water price, local water agencies leave ample room to the traders for price bargaining. The intermediary's capacity is not a sufficient condition for water markets' resilience in these cases, in that Yuanmou water market has a water bank company with strong capacity, whereas the other three cases do not.

\subsection{Explaining Why Some Local Water Markets Become Factitious}

We conducted the necessity analysis on the configurations whose outcome is 0 , by following the same procedure as in Section 4.1. Two conditions achieve the consistency score 1-the weak intermediary (bulletin board) and the forward water trade-indicating that, wherever a water markets is dominated by forward water trade, however with a weak intermediary, the market will be factitious (Table 6).

Table 6. Necessary conditions for a factitious water market.

\begin{tabular}{ccc}
\hline Conditions & Consistency & Coverage \\
\hline E & 0.666 & 0.285 \\
$\sim \mathrm{E}$ & 0.333 & 0.333 \\
$\mathrm{I}$ & 0.000 & 0.000 \\
$\sim \mathrm{I}$ & 1.000 & 0.500 \\
$\mathrm{P}$ & 0.666 & 0.333 \\
$\sim \mathrm{P}$ & 0.333 & 0.250 \\
$\mathrm{D}$ & 0.000 & 0.000 \\
$\sim \mathrm{D}$ & 1.000 & 0.500 \\
\hline
\end{tabular}


The complex solution for the factitious water market has two paths: $\sim E^{*} \sim I^{*} \sim P^{*} \sim D+E^{*} \sim I^{*} P^{*} \sim D=1$ (Table 7). Path 1 combines state-owned ownership, a weak intermediary, a fixed water price, and a long-term forward water contract. The water market in Zhongning $(\mathrm{ZN})$ is in this path in that: (1) By the time of contracting in 2016, the trading water entitlements had not been allocated to WUAs. In fact, the municipality of Zhongning authorized a state-owned water company to be the selling party. (2) The trading object would be over 2 million cubic meters of water per year potentially saved by the 12 WUAs, whose investments in water saving projects in the next 15 years were to be covered by the gains from the water trade, about 9 million yuan in sum. The water agency positioned itself as a broker instead of as an active designer, investing neither in the infrastructures indispensable for water trade nor in the institutions inspecting trading performance from 2016 to 2030 [69]. (3) The fixed water price focused on the supply side, with little concern about water scarcity and the supply uncertainties arising from long-term contracts. Aside from this, during a telephone semi-structured interview in December 2017, Director Liu of Zhongning County Water Affairs Bureau admitted that the thin market made the water trading even more fragile, when the power plant experienced difficulties in 2017 and found it impossible to pay the water price as promised.

Table 7. Complex solution for factitious water market.

\begin{tabular}{ccc}
\hline Path & $\sim \mathbf{E}^{*} \sim \mathbf{I}^{*} \sim \mathbf{P}^{*} \sim \mathbf{D}$ & $\mathbf{E}^{*} \sim \mathbf{I}^{*} \mathbf{P}^{*} \sim \mathbf{D}$ \\
\hline Case & $\mathrm{ZN}$ & $\mathrm{SD}, \mathrm{DT}$ \\
Raw Coverage & 0.333 & 0.666 \\
Unique Coverage & 0.333 & 0.666 \\
Solution Coverage & 1 & 1 \\
Solution Consistency & 1 & 1 \\
\hline
\end{tabular}

Path 2 covers two cases—the water markets in Dongping (SD) and Dongtiao River (DT) — combining privatized ownership, a weak intermediary, a competitive water price, and a long-term forward water contract.

In both cases, water agencies tried to privatize water entitlements. In Dongping, each household in irrigation areas was entitled 160 cubic meters of water per $\mathrm{mu}(=0.0667$ hectares) per year and was able to trade the water to surplus purchasers (interview: Head of Dongping County Water Affairs Bureau, anonymous). In Dongtiao River basin, water entitlements were clearly defined for 119 industrial water users before 2015, and the WUAs got certificates verifying their ownership of the water resources in the communal reservoirs [70]. The local water agencies both brokered the water trade. Whereas the contracts in Dongping could be traced to the integrated platform for public resources transference, those in Dongtiao River are not available as the trading platform is not yet publicly open (interview: Head of Hangzhou City Water Affairs Bureau, anonymous). Nevertheless, the above efforts did not lead to water market resilience. After several cases of water trades in Dongping, the promising water market lost its attraction for irrigators, mainly because the coal companies could not afford to pay on time; and similar problems were experienced in Dongtiao River (interview: Head of Hangzhou City Water Affairs Bureau, anonymous; Head of Dongping County Water Affairs Bureau, anonymous). Both cases attempted to establish an inclusive water market, i.e., Dongtiao River even tried to broker a water trade contract between two companies (Huawang and Qingshu) when the former promised to transfer 0.1 million cubic meters of surplus water entitlements per year to the vegetable production company (Qingshu) for three years [66]. However, the local agencies did not get involved in the establishment of a spot water market because it is more time-consuming than the inter-sectoral forward water trade (interview: Head of Hangzhou City Water Affairs Bureau, anonymous; Head of Dongping County Water Affairs Bureau, anonymous).

\section{Conclusions}

This study aimed to examine what contextual factors, in configurations, contribute to the resilience of water markets in China. To do this, we distinguished between resilient and factitious water 
markets as two outcome variables. We also developed an empirical framework inspired by market environmentalism and distilled four conditions explaining the outcome variance. Using csQCA, we updated the understanding of sufficient solutions driving a resilient water market. Given the limited attention paid to the resilience of water markets in the literature, our work at least opens up the research to others for confirmation or falsification [71].

When we looked at the resilient water markets in China, we could not identify any necessary conditions. This contradicts some findings in the water market literature, where private ownership of water rights [33] and strong intermediary have been recognized as necessary conditions attributing to a resilient water market [29]. Our findings prove that they are unnecessary but sufficient conditions and have to operate with other conditions to achieve a positive outcome. Two solutions display such configurational complexity of water markets' resilience, i.e., Path 1 includes strong intermediary, uncompetitive price, and forward water trade, while Path 2 includes privatization of water entitlements, spot contract, and competitive pricing. This is in line with the ideas on water market security proposed by Rosegrant, whereby a thick spot market would be a cheaper option and provide the same security as the forward market does [72]. This is meaningful for policymakers, especially those with mandatory powers and ambitions in water market design, because state-owned hydraulic infrastructures and water banks are not universally necessary; they are only needed when the water market is dominated by forward water trade.

Regarding the limitations of this study, we did not critically measure the resilience of water markets, and such simplified operationalization of the concept, although acceptable in a case study, could lead to surprises in both management and future research. The four explanatory variable conditions distilled from the market environmentalism literature are far from being comprehensive. As the best way to enhance resilience is a broader basin of attraction, albeit with a similar research design, we still need to discover more conditions, and, in consequence, more casual configurations for a more convincing explanation. We also did not include the social flexibility to change, i.e., water governance in our case, in the empirical framework because this variable does not feature much in the Chinese context; this in turn constrains the generalizability of the findings to global water markets. As to the empirical evidence, the ten cases, although representative, all come from China, carrying properties of an authoritarian regime [73]. The findings may be illuminating to Chinese scholars, but they have to be checked against cases from other countries. Future research could aim to increase the number of cases, especially those from both developed and developing countries. Richness of cases is a precondition for the elaboration of our empirical framework, required by the QCA method. Even though the ten cases are an acceptable number in QCA, with four conditions the number of observed configurations is limited. In particular, our analysis of factitious water markets builds on just three empirical observations. Once we can collect more similar cases, the QCA might produce more configurations and complex solutions explaining the absence of resilience in water markets.

Author Contributions: Conceptualization, Y.L.; Methodology, Y.L.; Software, Z.Z.; Formal Analysis, Y.L.; Investigation, P.L.; Resources, P.L.; Writing-Original Draft Preparation, Y.L. and Z.Z.; Writing-Review \& Editing, Y.L. and Z.Z.

Funding: This research is funded by The National Natural Science Foundation of China (71774024); by Social Science \& Humanity Foundation of Ministry of Education of China (17YJA630064); by Social Science Foundation of Liaoning Province (L17BGL020).

Conflicts of Interest: The authors declare no conflict of interest.

\section{References}

1. Xu, T.; Zheng, H.; Liu, Y.; Wang, Z. Assessment of the water market in the Xiying Irrigation District, Shiyang River Basin, China. J. Water Resour. Plan. Manag. 2016, 142, 04016021. [CrossRef]

2. Wang, Y. A simulation of water markets with transaction costs. Agric. Water Manag. 2012, $103,54-61$. [CrossRef]

3. Jiang, Y. China's water scarcity. J. Environ. Manag. 2009, 90, 3185-3196. [CrossRef] [PubMed] 
4. Ravnborg, H.M. Water governance reform in the context of inequality: Securing rights or legitimizing dispossession? Water Int. 2016, 41, 928-943. [CrossRef]

5. Grantham, T.E.; Viers, J.H. 100 years of California's water rights system: Patterns, trends and uncertainty. Environ. Res. Lett. 2014, 9, 084012. [CrossRef]

6. Wang, Y.; Wan, T.; Biswas, A.K. Structuring water rights in China: A hierarchical framework. Int. J. Water Resour. Dev. 2017, 34, 418-433. [CrossRef]

7. Ministry of Water Resources of China. 2005. Available online: www.wanfangdata.com.cn/details/detail.do? _type=perio\&id=sljsygl200503004 (accessed on 11 January 2018).

8. Yuan, S. The dispute of water purchasing: Operating of the water market in irrigation districts-Investigation into dispute concerning water in Shiqiao Town of Hubei province. J. Gansu Inst. Public Adm. 2010, 6, 50-59. (In Chinese) [CrossRef]

9. Shen, M.H. Water rights trading and contractual arrangements-Taking China's first buying river case as an example. Manag. World 2006, 8. (In Chinese) [CrossRef]

10. Binger, B.R.; Hoffman, E. Institutional persistence and change-The question of efficiency. J. Inst. Theor. Econ. 1989, 145, 67-84.

11. Moore, S.M. The development of water markets in China: Progress, peril, and prospects. Water Policy 2015, 17, 253-267. [CrossRef]

12. Zhu, X.F. Inter regional diffusion of policy innovation in China: A comparative case study. Asian J. Political Sci. 2017, 25, 266-286. (In Chinese) [CrossRef]

13. Wheeler, S.A.; Loch, A.; Crase, L.; Young, M.; Grafton, R.Q. Developing a water market readiness assessment framework. J. Hydrol. 2017, 552, 807-820. [CrossRef]

14. Bauer, C.J. Water conflicts and entrenched governance problems in Chile's market model. Water Altern. 2015, $8,147-172$.

15. Brookshire, D.S.; Colby, B.; Ewers, M.; Ganderton, P.T. Market prices for water in the semiarid west of the United States. Water Resour. Res. 2004, 40,1-8. [CrossRef]

16. Shi, M.; Wang, X.; Yang, H.; Wang, T. Pricing or quota? A solution to water scarcity in oasis regions in China: A case study in the Heihe River Basin. Sustainability 2014, 6, 7601-7620. [CrossRef]

17. Wang, Y.; Shu, Q.; Wu, J. A review of water rights market studies and a prospect of research on Chinese water rights market. China Popul. Resour. Environ. 2017, 27, 87-100. (In Chinese)

18. Huang, G. From water-constrained to water-driven sustainable development-A case of water policy impact evaluation. Sustainability 2015, 7, 8950-8964. [CrossRef]

19. Zhang, L.; Heerink, N.; Dries, L.; Shi, X. Water users associations and irrigation water productivity in northern China. Ecol. Econ. 2013, 95, 128-136. [CrossRef]

20. Morris, R.C.; Ernest, N. An Introduction to Logic and Scientific Method; Harcourt, Brace and Company: San Diego, CA, USA, 1934; p. 267.

21. Gallopin, G.C. Linkages between vulnerability, resilience, and adaptive capacity. Glob. Environ. Chang. Hum. Policy Dimens. 2006, 16, 293-303. [CrossRef]

22. Gunderson, L.; Holling, C.S. Panarchy: Understanding Transformations in Human and Natural Systems; Island Press: Washington, DC, USA, 2001.

23. Payne, M.T.; Smith, M.G. Price determination and efficiency in the market for water rights in New Mexico's Middle Rio Grande Basin. Int. J. Water Resour. Dev. 2013, 29, 588-604. [CrossRef]

24. Wang, Y.B.; Liu, D.; Cao, X.C.; Yang, Z.Y.; Somg, J.F.; Chen, D.Y.; Sun, S.K. Agricultural water rights trading and virtual water export compensation coupling model: A case study of an irrigation district in China. Agric. Water Manag. 2017, 180, 99-106. [CrossRef]

25. Urquiza, A.; Billi, M. Water markets and social-ecological resilience to water stress in the context of climate change: An analysis of the Limarí Basin, Chile. Environ. Dev. Sustain. 2018. [CrossRef]

26. Kharrazi, A.; Fath, B.; Katzmair, H. Advancing empirical approaches to the concept of resilience: A critical examination of panarchy, ecological information, and statistical evidence. Sustainability 2016, 8, 935. [CrossRef]

27. Zaman, A.M.; Malano, H.M.; Davidson, B. An integrated water trading-allocation model, Applied to a water market in Australia. Agric. Water Manag. 2009, 96, 149-159. [CrossRef]

28. Pigram, J.J. Property-rights and water markets in Australia-An evolutionary process toward institutional reform. Water Resour. Res. 1993, 29, 1313-1319. [CrossRef] 
29. Möller-Gulland, J.; Donoso, G. A typology of water market intermediaries. Water Int. 2016, 41, $1016-1034$. [CrossRef]

30. Fiss, P.C.; Marx, A.; Cambré, B. Chapter 1 configurational theory and methods in organizational research: Introduction. Config. Theory Methods Organ. Res. 2013, 38, 1-22. [CrossRef]

31. Gordon, J.E.; Stewart, M.B. Structures; Plenum Press: Harmondsworth, UK, 1978.

32. Tolbert, P.S.; Zucker, L.G. Institutional sources of change in the formal-structure of organizations-The diffusion of civil-service reform, 1880-1935. Adm. Sci. Q. 1983, 28, 22-39. [CrossRef]

33. Rosegrant, M.W.; Binswanger, H.P. Markets in tradable water rights: Potential for efficiency gains in developing country water resource Allocation. World Dev. 1994, 22, 1613-1625. [CrossRef]

34. McCann, L.; Easter, K.W. A framework for estimating the transaction costs of alternative mechanisms for water exchange and allocation. Water Resour. Res. 2004, 40, 1-6. [CrossRef]

35. Caplan, A.J. Incremental and average control costs in a model of water quality trading with discrete abatement units. Environ. Resour. Econ. 2008, 41, 419-435. [CrossRef]

36. Carpenter, S.; Walker, B.; Anderies, J.M.; Abel, N. From metaphor to measurement: Resilience of what to what? Ecosystems 2001, 4, 765-781. [CrossRef]

37. Ferguson, B.C.; Brown, R.R.; Deletic, A. Diagnosing transformative change in urban water systems: Theories and frameworks. Glob. Environ. Chang. Hum. Policy Dimens. 2013, 23, 264-280. [CrossRef]

38. Bakker, K. The business of water: Market environmentalism in the water sector. Annu. Rev. Environ. Resour. 2014, 39, 469-494. [CrossRef]

39. Dai, T.S.; Gu, B.Y.; Zhao, W.H. Study on the market power in water rights market. In Proceedings of the 4 th International Conference on Wireless Communications, Networking and Mobile Computing, Dalian, China, 12-17 October 2008; pp. 1-5.

40. Anderson, T.L.; Leal, D.R. Free Market Environmentalism for the Next Generation; Palgrave: Basingstoke, UK, 2015; pp. 1-200.

41. Scott, W.R. Institutions and Organizations; Sage Publications: Newbury Park, CA, USA, 2001; pp. 69-89.

42. Oliver, C. The antecedents of deinstitutionalization. Organ. Stud. 1992, 13, 563-588. [CrossRef]

43. Araral, E.; Wang, Y. Water governance 2.0: A review and second generation research agenda. Water Resour. Manag. 2013, 27, 3945-3957. [CrossRef]

44. Slaughter, R.A.; Wiener, J.D. Water, adaptation, and property rights on the snake and Klamath Rivers. J. Am. Water Resour. Assoc. 2007, 43, 308-321. [CrossRef]

45. Sibly, H.; Tooth, R. Bringing competition to urban water supply. Aust. J. Agric. Resour. Econ. 2008, 52, $217-233$. [CrossRef]

46. Libecap, G.D. The tragedy of the commons: Property rights and markets as solutions to resource and environmental problems. Aust. J. Agric. Resour. Econ. 2009, 53, 129-144. [CrossRef]

47. Barzel, Y. Economic Analysis of Property Rights; Cambridge University Press: Cambrige, UK, 1997; pp. 147-179.

48. Bjornlund, H.; McKay, J. Aspects of water markets for developing countries: Experiences from Australia, Chile, and the US. Environ. Dev. Econ. 2002, 7, 769-795. [CrossRef]

49. Ching, L. The paradox of social resilience: Explaining delays in water infrastructure provision in Kathmandu. Water Altern. 2018, 11, 61-85.

50. Lin, C.; Nicholas, P.; Bethany, C. Water pricing in Australia: Unbundled politics, accounting, and water pricing. In Water Pricing Experiences and Innovations; Springer: Berlin/Heidelberg, Germany, 2015; pp. 15-39.

51. Fridman, A. Water pricing reform analysis: Alternative scenarios. J. Econ. Policy Reform 2015, 18, $258-266$. [CrossRef]

52. Saglam, Y. Supply-based dynamic Ramsey pricing: Avoiding water shortages. Water Resour. Res. 2015, 51, 669-684. [CrossRef]

53. Calatrava, J.; Garrido, A. Modelling water markets under uncertain water supply. Eur. Rev. Agric. Econ. 2005, 32, 119-142. [CrossRef]

54. Tisdell, J.G. Water markets in Australia: An experimental analysis of alternative market mechanisms. Aust. J. Agric. Resour. Econ. 2011, 55, 500-517. [CrossRef]

55. Brennan, D. Water policy reform in Australia: Lessons from the Victorian seasonal water market. Aust. J. Agric. Resour. Econ. 2006, 50, 403-423. [CrossRef]

56. Tisdell, J.G.; Ward, J.R. Attitudes toward water markets: An Australian case study. Soc. Nat. Resour. 2003, 16, 61-75. [CrossRef] 
57. Hadjigeorgalis, E. Dealing with uncertainty: Water trading in the Chilean agriculture. Cuadernos de Economia 2004, 41, 3-34.

58. Rihoux, B.; Ragin, C.C. Configurational Comparative Methods: Qualitative Comparative Analysis (QCA) and Related Techniques; Sage Publications: Newbury Park, CA, USA, 2009; p. 21.

59. Ministry of Water Resources of China. Office Document: Water Law of the People's Republic of China. 2002. Available online: www.china.org.cn/english/government/207454.htm (accessed on 29 August 2002). (In Chinese)

60. National Development and Reform Commission. Office Document: Notice on Promoting the Comprehensive Reform of Agricultural Water Price. 2017. Available online: www.ndrc.gov.cn/zcfb/zcfbtz/201706/ t20170613_850553.html (accessed on 6 June 2017). (In Chinese)

61. Ministry of Water Resources of China. Office Document: Interim Measures for the Administration of Water Right Transactions. 2016. Available online: www.gov.cn/zhengce/2016-05/22/content_5075679.htm (accessed on 19 April 2016). (In Chinese)

62. Ordanini, A.; Parasuraman, A.; Rubera, G. When the recipe is more important than the ingredients. J. Serv. Res. 2013, 17, 134-149. [CrossRef]

63. Ragin, C.C. The Comparative Method: Moving beyond Qualitative and Quantitative Strategies; University of California Press: Oakland, CA, USA, 1987; p. x.

64. Ragin, C.C.; Davey, S. fs/QCA [Computer Programme]; Version 3.0; University of California: Irvine, CA, USA, 2017.

65. Barry, C.; Glaesser, J. Qualitative work and the testing and development of theory: Lessons from a study combining cross-case and within-case analysis via Ragin's QCA. Forum Qual. Soc. Res. 2012, 13. [CrossRef]

66. Sun, F. The Success of Water Right Trade Wxploration. Available online: www.waterinfo.com.cn/special/ 219/251/257/201603/t20160330_2696.html (accessed on 30 March 2016). (In Chinese)

67. Qu, J. Water Right Trade in Manasi Country Make the Rational Utilization of Water Resources. Available online: roll.sohu.com/20140925/n404656844.shtml (accessed on 25 September 2014). (In Chinese)

68. State Council of China. Office Document: Plan of the Available Supply for Water Distribution for the Yellow River. 1987. Available online: www.gov.cn/zhengce/content/2011-03/30/content_3138.htm (accessed on 30 March 2011). (In Chinese)

69. China Water Exchange. Water Trade in Ningxia. Available online: cwex.org.cn/2016/ssal_0926/132.html (accessed on 26 September 2016). (In Chinese)

70. Guan, G.Q. The Success of Water Right Revelotion in Hangzhou. Available online: hzdaily.hangzhou.com. cn/hzrb/html/2015-02/11/content_1899655.htm (accessed on 11 February 2015). (In Chinese)

71. Popper, K.R. Conjectures and Refutations; Routledge and Kegan Paul: London, UK, 1963; pp. 33-39.

72. Easter, K.W.; Rosegrant, M.W.; Dinar, A. Formal and informal markets for water: Institutions, performance, and constraints. World Bank Res. Obs. 1999, 14, 99-116. [CrossRef]

73. Akiyama, T.; Kharrazi, A.; Li, J.; Avtar, R. Agricultural water policy reforms in China: A representative look at Zhangye City, Gansu Province, China. Environ. Monit. Assess. 2017, 190, 9. [CrossRef] [PubMed] 